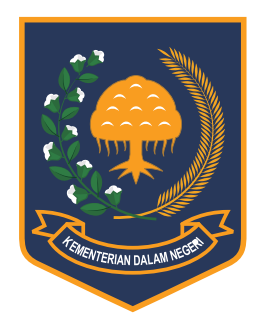

JURNAL BINA PRAJA

e-ISSN: 2503-3360 | p-ISSN: 2085-4323

Accreditation Number

21/E/KPT/2018

http://jurnal.kemendagri.go.id/index.php/jbp/index

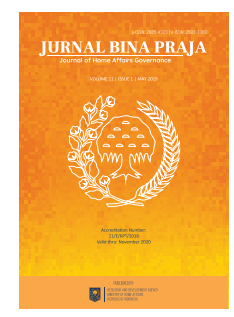

\title{
EVICTIONS IN JAKARTA FROM THE VIEW OF UTILITARIANISM
}

\author{
Nurul Annisa Hamudy* \\ Sekolah Tinggi Filsafat Driyarkara \\ Jln. Cempaka Putih Indah 100A \\ Jembatan Serong, Rawasari Jakarta 10520
}

Received: 1 March 2019; Accepted: 30 April 2019; Published online: 31 May 2019

DOI: $10.21787 / \mathrm{jbp} .11 .2019 .75-86$

\begin{abstract}
DKI Jakarta Government's eviction policy is often considered to be wrong or has a negative image (even violating the Human Rights) because eviction is synonymous with riot, coercion, expulsion, and always ends in conflict. Although according to the utilitarianism philosophy, no actions, including evictions, are inherently wrong. All actions or regulations by itself are neutral. What gives moral values to actions or regulations are its consequences. The objective of this study was to determine the positive consequences of eviction actions by using the philosophical perspective of Utilitarianism. The study used descriptive and literature review methods, as well as qualitative approach, the results of the study showed that eviction policies were justified in the utilitarian view, Eviction of a handful of residents living on the riverbanks was done to normalize the riverbank and green areas to save millions of DKI Jakarta residents from floods. The main objective of the eviction was the public interest. Therefore, evictions must be conducted for the greater good, benefiting as many people as possible and carried out in ways that humanize people.
\end{abstract}

Keywords: Eviction, Moral Values, Benefits, Ethics of Utilitarianism.

\section{INTRODUCTION}

This study was conducted on evictions carried out by the DKI Jakarta Government. The eviction referred to in this study is the expulsion of residents from their homes by the local government for violating regional regulations (Human Rights Watch, 2011). The land occupied by residents is a state-owned land that is not intended for settlements, but public facilities, such as riverbanks, green lanes, and the like (Prihatin, 2014). This study seeks to provide an overview and justification that not all evictions are negative or violating human rights (HAM), but it is basically positive when viewed from other perspectives, such as the utilitarianism. It brings benefit to society.

Conceptually, utilitarianism comes from the Latin word utilis, which means useable, useful, advantageous or beneficial. This is an understanding or moral philosophy that emphasizes the principle of benefit or usefulness as the most basic moral principle. In Utilitarianism, the purpose of moral action is to maximize the utility or happiness for as many people as possible (Osifo, 2015). The principle of utility is used as a benchmark for assessing and making decisions on whether an action is morally justified or not (Reinhart, F, 2015). Thus, the moral judgment for an action or the enforcement of a moral rule is determined by how much more good consequences compared with the adverse consequences arising from it.

The concept is useful to determine the decision to be taken by a government official out of several choices. Sometimes these choices are dilemmatic, on the one hand, it brings benefits to society, and on the other hand, there is a group of community that is disadvantaged. Therefore, the problem in public decision decisions is not only related to legal and political issues but also the issue of moral responsibility (Haryatmoko, 2013, p. 60). The public would like to remind the moral responsibility of public officials in their decision-making process to avoid doing more harm than benefits the people.

Utilitarianism claims to answer the question of what the benchmarks of moral actions are. The principle of utility is used to assess and make

\footnotetext{
* Corresponding Author

Phone : +6281281224344

Email : nurulannisahamudy@gmail.com
} 
decisions to see whether an action is morally justified or not. Thus, the rationality of moral judgment for action is determined by how an action resulting in more good consequences that the bad ones. Thus, for the utilitarianism, the right action among all the actions that may be taken is the one that, as far as it can be determined, is the one that will produce the greatest good for the greatest number of people (Suseno, 1979, p. 94).

We can say that the general features of the utilitarian are, First, it is critical, refusing to obey the current norms without questioning it. Second, it is rational, the morality for action is determined by how much it will produce more good consequence compared with the bad. Third, it is teleological, an action's right or wrong is determined by the purpose they serve. Fourth, it is universal in the sense that this ethical theory pays attention to the public interest and not only personal interests (Sudarminta, 2013, pp. 127-129).

An understanding of utilitarianism at least helps us to know which alternatives should be chosen when facing various possible moral situations out there, especially in public policies implemented by the government (Bromell, 2012). For this reason, utilitarianism philosophy is chosen and used as a basis in seeing and analyzing one example of public policy that attracts the public's attention. The evictions that are often carried out by regional governments are interesting, important, and are actual cases to be analyzed philosophically.

Evicted communities are located in various areas throughout the city: slums beneath the railroad bridges built from collected waste, twostory brick and concrete houses in the heart of the city, simple buildings built on reclaimed land by fishermen, and villages with agricultural areas in the suburbs (Januardy, Achmadi, \& Fortuna, 2016).

In 2007-2012, the Jakarta Legal Aid Institute (LBH) noted that there were approximately 3,200 people evicted every month. Throughout the history of the city administration of Jakarta, this figure is quite high. The eviction was then continued by the next government as illustrated through 2014 budget plan: The DKI Jakarta Provincial Government and the Public Works Agency allocated a budget of up to 6 Trillion Rupiah to carry out evictions at 131 points in the capital (Januardy, 2015). LBH again noted that there had been 79 eviction cases in DKI Jakarta in January-September 2018 comprise of 277 households and 864 business units. The number of points and eviction victims is slightly lower than the same period in 2017 which recorded 91 cases of eviction (Albajili, Latifa, \& Fitri, 2018).

The purpose of land use from these eviction areas is for reservoirs, water normalization areas, construction of city parks, and other needs (Januardy, 2015). Especially for the construction of reservoirs, normalization and evictions are carried out on a large scale to anticipate the floods that often hit the city of Jakarta due to the many illegal buildings occupying the area around the riverbank (Soemarwi, 2016).

One case in point is the eviction of residential buildings on the banks of Ciliwung River, Bukit Duri, South Jakarta, which were carried out to normalize the river (Purnamasari, 2016). Evictions were carried out solely to anticipate the flood that often hit the area. Although it has not fully succeeded in making the surrounding area free from flood, at least the normalization efforts manage to reduce floods by more than 50 percent (Soemarwi, 2016). The normalization of the Ciliwung river increases its capacity to hold the water almost three times its previous capacity. Areas that are gradually becoming flood-free include; Bukit Duri, Kebon Manggis, Kampung Melayu, Kampung Pulo, Kebon Baru, Bidaracina, Cikoko, Cawang, Pengadegan, Rawajati, Cililitan, Tanjung Barat, Balekambang, Pejaten Timur, Jagakarsa, and Pasar Minggu (Saudale, Tambun, Purnamasari, \& DAS, 2016).

Ciliwung has long been the cause of Jakarta's floods that have not been remedied (Mirah Sakethi, 2010). This failure is because the DKI Jakarta Provincial Government was unable to clear-up the illegal housing on the banks of the Ciliwung River. During Governor Jokowi's era and continued by Basuki Tjahaja Purnama (BTP), this area began to be controlled, by relocating thousands of residents who were on the banks of Ciliwung River (Fitrianti \& Fadhilah, 2018). This must be done to restore Ciliwung width to its normal width (35-50 meters), followed by reinforcement of the riverbanks, levee construction, and inspection roads construction of 6-8 meters wide along the river. As a result, the capacity of the river nearly tripled, from 200 $\mathrm{m} 3 /$ second to $570 \mathrm{~m} 3 / \mathrm{second}$, to anticipate the occurrence of floods like in previous years (Wigati \& Soedarsono, 2016).

It means, eviction cases are not always negative, if the eviction is carried out for the greater good as in the case above. This is in line with the universal principle of the utilitarianism. The moral norm is not based on the consequences for a person, but the good consequences for the whole society. The interests of as many people as possible must be one of the main criteria in making a decision for an action (McGee, 2004).

In the context of eviction, some groups certainly do not fully agree that evictions can be considered to provide utility values in the view of utilitarianism, naturally, there are parties that agree 
with it and those who are against it (Insidejakarta. com, 2018). For those who are against it, evictions can cause damage to neighborhood and family networks, damage to the stability of life such as working, schooling, and demolishing residential assets. Eviction is also considered as a violation of the right to live and the right to have a life which can be categorized as inhumane acts, even considered as a crime against human rights. But on the other side, there are those who believe that eviction must be done because the eviction will result in a more comfortable and livable city (Baujard, 2013).

Based on data from the Population Office, every year the city of Jakarta is invaded by approximately 250 thousand new arrivals from various regions in Indonesia. Most of the migrants did not have adequate education and skills, they were only able to become unskilled workers with low-income levels. This condition causes many of them to live in illegal settlements or conducting trade in improper locations (Prihatin, 2014).

This is one of the factors that trigger the evictions by the government, evictions have become a phenomenon as well as a social reality. Eviction becomes an interesting issue to be studied in depth using utilitarianism ethics that opens the door for a moral appreciation that is very different from the deontological ethics, which solely emphasizes on the obligation aspect in an action without questioning the benefit of doing that action. In utilitarianism, actions by themselves are not obligatory or prohibited. All actions are neutral. What determines the moral values of those actions are their consequences (Suseno, 1979). In the utilitarianism perspective, the eviction case is an effective action if carried out with a specific purpose resulting in the maximum benefit for all people in the region.

So far there have been very few studies that have been carried out on that perspective. There are several utilitarianism studies that have discussed the phenomenon of eviction, but none have specifically reviewed the ethical perspective of. For example, a report of a study conducted by Human Rights Watch (2006). The focus of the discussion was to trace data and facts throughout the nine years of the then Jakarta Governor, Sutiyoso. The study revealed that tens of thousands of people were forced to demolish their homes and destroy their personal property with only a little prior notice and without proper procedures or compensation.

The discussion of eviction in a legal perspective was also carried out by the Legal Aid Institute (Lembaga Bantuan Hukum/LBH) (Januardy, 2015; Januardy et al., 2016). Januardy et al. describe the facts in the fields in all cases of forced evictions in the DKI Jakarta area from January to August 2015 and January to September 2016. The study report revealed that forced evictions were not the solution to urban planning and the welfare of the poor. Forced evictions were considered to result in human rights violations of the affected people, such as violations of the right to housing, the right to work, the right to security, the right to private ownership, the right to health, the right to education, the right to identity, and various other rights which further impoverish the affected residents (Soemarwi, 2017).

Another further study, Sabrina (2017) was conducted in urban sociology on the social construction of the community in the eviction of land in Gunung Anyar Village. The study has shown that the external factors i.e. the economic factor and the education level of the evicted people affects their conception on the land eviction. The evicted people who have low education levels and middle to lower economic conditions have negative construct on the land eviction. Meanwhile, the evicted people who have a high education level and have a well-established economy have a positive construct on the land eviction. They see the eviction as a Surabaya City Government program to improve the economy of the East Surabaya community by building infrastructure to facilitate transportation and the economy.

Based on the results of the above studies, it seems that a philosophical perspective has not been used by urban researchers or observers. Therefore, this study seeks to fill the gap in the study on eviction cases by looking at it from the utilitarianism ethical point of view. This study focuses on discussing evictions in the context of river normalization, reviewing it from the utilitarianism point of view.

\section{MeTHOD}

This study combined descriptive methods and document analysis. The descriptive method was used to describe the state of the eviction and the community of "victims" of eviction as an analysis unit based on facts as they were presented (Sugiyono, 2015). The literature review method was used to gather relevant information on the policy of eviction from the view of the Utilitarianism philosophy by Jeremy Bentham and John Stuart Mill. This information was obtained through reviewing books, scientific works, thesis, dissertations, encyclopedias, internet, and other sources (Zed, 2004). The approach in this study was a qualitative approach since the issue of eviction in the utilitarianism perspective was considered to be multidimensional (Alwasilah, 2003). The 
facts and data were collected from the news in mainstream mass media to enrich the analysis. The study was conducted for two months, from the end of December 2018 to the end of February 2019. The location of this study was the DKI Jakarta Province in the designated areas for riverbanks normalization. The reason for choosing the area was because Jakarta, the capital of the country, continues to suffer from floods every year due to the many illegal settlements around the normalization area, evictions were inevitable in the interest of the community to have more comfortable and floodfree public spaces.

\section{RESULTS AND DISCUSSION}

Jakarta is an example of a city that is very densely populated, and its public spaces are still not adequately regulated. The urbanization phenomenon is also inevitable (Pravitasari, 2018). Jakarta is still a city of dreams for many to change their destiny when the opportunity to get jobs in rural areas and other regions is getting smaller. (Purwantini, 2016). But this urbanization is one of the factors driving the increasing social problems in Jakarta (Ibrahim, 2005, pp. 75-76). The migrants are not only unskilled but also have no financial ability to buy or rent a place to stay. As a result, they often occupy places on the riverbanks and suffers from floods (Abraham, Lubis, Indrawan, \& Fachrudin, 2014).

\section{A. River Normalization and Its Positive Impacts}

Since the colonial era, Jakarta has always been suffering from floods. Even now, floods still hit the Jakarta area regularly. Based on various sources, the average flood in Jakarta occurred at the beginning of the year (Nailufar, 2018b). However, in 2013, the flood was due to the collapse of the Latuharhary embankment. Table 1 are flood data in Jakarta from 2012-2015.

Floods are basically caused by two things (Waryono, 2002). First, natural conditions and events contribute to the flood. These includes: the intensity of rainfall that occurs in certain months; the topography of the area which is a lowland with relatively horizontal slopes, as well as a low land basin as a water catchment area; geologically certain lands have a water-resistant soil that makes it difficult to absorb water; narrowing of the river channel and silting of the river due to the deposition of materials carried from upstream. Second, as the result of human activities, which include: changes in land use from what originally was lakes, swamps, rice fields, vacant land, converted into settlements or other buildings; illegal logging of forests in the upstream catchment area, which not only results in floods in the rainy season but also drought in the dry season; narrowing of riverbanks, due to human settlements on its banks. Floods in urban areas, especially in the Jakarta, are usually viewed from the river system which is influenced by its physical characteristics and the rainfall, however, generally it is caused by human settlement on the floodplain, changes in land use, high rainfall, narrowing of the river channels, and sedimentation in river bodies. Therefore, the eviction and normalization were the priority programs of DKI Jakarta Governor Joko Widodo, which was then continued by the Governor BTP.

The normalization of river flows and green open area are done to anticipate floods caused by slums and illegal settlements near Jakarta's rivers. The evictions are carried out to return the land to their original functions. Not surprisingly, as an effort to deal with floods and strengthen the good governance in his government, Governor BTP often conducted eviction during his tenure (Widodo, 2018, pp. 78-79).

Table 1.

Flood data in Jakarta from 2012-2015

\begin{tabular}{clcc}
\hline Number of Areas & \multicolumn{1}{c}{ Time } & Casualties & Refugee \\
\hline 10 District & $\begin{array}{l}22 \text { November } 2012 \text { (lasted } \\
\text { for } 9 \text { days) }\end{array}$ & 820 people \\
\hline 35 District & $\begin{array}{l}22 \text { November } 2013 \text { (lasted } \\
\text { for } 15 \text { days) }\end{array}$ & 19 people & 83,930 people \\
\hline 37 District & January-February 2014 & 23 people & 62,819 people \\
\hline 38 District & $\begin{array}{l}8 \text { February } 2015 \text { (lasted for } \\
7 \text { days) }\end{array}$ & 5 people & 231,566 people
\end{tabular}

Source: detik.com, $2017 b$ 
Table 2.

Eviction conducted within two years:

\begin{tabular}{|c|c|c|c|}
\hline No. & Areas & Time & Description \\
\hline 1 & $\begin{array}{l}\text { Prof Sedyatmo Toll Road, Pejagalan } \\
\text { Village, Penjaringan District, North } \\
\text { Jakarta. }\end{array}$ & 29 February 2016 & $\begin{array}{l}\text { - In } 2015 \text { the illegal settlement was demolished, but residents returned } \\
\text { to occupy the land under the toll road. In this eviction, no residents } \\
\text { were relocated to the flat, because they were not Jakarta's legal } \\
\text { residents and they occupy the state's land. }\end{array}$ \\
\hline 2 & Kampung Pulo, Jakarta Timur. & August 2015 & $\begin{array}{l}\text { - Hundreds of houses were torn down by the DKI Jakarta Government } \\
\text { here to normalize the Ciliwung river. River sedimentation was dredged } \\
\text { to increase the river capacity to handle the massive amount of } \\
\text { rainwater sent down from Bogor and avoid it to overflow into the } \\
\text { residents' settlements. } \\
\text { - The affected residents were relocated to Rusunawa Jatinegara Barat, } \\
\text { Rusun Cibesel and Rusun Pulogebang in East Jakarta. }\end{array}$ \\
\hline 3 & Bidaracina, Jakarta Timur. & 2016 & $\begin{array}{l}\text { - Bidaracina is one of the areas impacted by the Ciliwung River } \\
\text { normalization program. The eviction in this area was conducted to build } \\
\text { a canal to redirect the flood water. According to Ahok, Bidaracina and } \\
\text { Kampung Pulo were different cases when seen from the land ownership } \\
\text { of the settlement. } \\
\text { - The land in Kampung Pulo owned by the state and the residents have } \\
\text { no land ownership certificate. While in Bidaracina, the residents have } \\
\text { the certificate of ownership for their land. As such the Provincial } \\
\text { Government paid compensation to the landowners of Bidaracina. }\end{array}$ \\
\hline
\end{tabular}

4 Bukit Duri, Jakarta Selatan.
4-12 January 2016

The eviction was conducted to normalize the Ciliwung River. The affected residents were relocated to Rusunawa Cibesel and Rusunawa Pulogebang in East Jakarta.

- Previously, this area also had an eviction. Ninety-seven houses on the riverbanks of Ciliwung were demolished. At that time the residents of Bukit Duri requested that they would be relocated to a "Kampung Deret" (a low story affordable housing complex).

28 September 2016 - The provincial government also demolished hundreds of other illegal buildings in RW 9, RW 10, RW 11, RW 12, Kelurahan Bukit Duri. The provincial government also demolished hundreds of other illegal buildings in RW 9, RW 10, RW 11, RW 12, Kelurahan Bukit Duri. Only 11 buildings in RW 10 remains.

- The 314 households affected by the eviction offered no resistance.
- RW 06 of Pinangsia Village, District Tamansari West Jakarta has three kampungs: RT04 Kunir, RT 05 and RT 06 Balokan.

These Kampungs existed since 1970 and are all on the riverbanks of the Anak Kali Ciliwung, the tributary of Ciliwung River.
6 Kemayoran Central Jakarta.

7 Pluit Dam, North Jakarta.

2012

2014

2015
- Eviction of the 1,000 m2 of land in Ketapang Kebon Kosong, Kemayoran, Central Jakarta by the Central Jakarta Tramtib (local government security officers).

\begin{tabular}{|c|c|c|c|}
\hline & & $\begin{array}{l}2014 \\
2015\end{array}$ & $\begin{array}{l}\text { - } 2,000 \text { buildings are demolished in..... } \\
\text { - The second stage demolishment target was } 2,000 \text { buildings. } \\
\text { - The third stage demolishment target was } 3,000 \text { buildings. }\end{array}$ \\
\hline 8 & Menteng Dalam, Jakarta Selatan. & & $\begin{array}{l}\text { - A total of } 185 \text { illegal buildings over a 500-meter long channel on Jalan } \\
\text { Menteng Pulo, RT } 05 \text { RW 14, Menteng Dalam, South Jakarta, are } \\
\text { demolished by the Public Order Unit (Satpol PP). }\end{array}$ \\
\hline 9 & Kali Krukut, Jakarta Pusat. & 30 September 2015 & $\begin{array}{l}\text { - Hundreds of illegal buildings on the banks of the Krukut River, North } \\
\text { Petojo, Gambir, Central Jakarta, was forcibly demolished by Satpol PP } \\
\text { officers. }\end{array}$ \\
\hline
\end{tabular}

\section{Evictions in Jakarta from the View of Utilitarianism}




\begin{tabular}{|c|c|c|c|}
\hline No. & Areas & Time & Description \\
\hline 10 & Pasar Ikan, North Jakarta. & March-April 2016 & $\begin{array}{l}\text { This area is to be converted into a maritime tourism area. } \\
\text { The Pasar Ikan residents were relocated to Rusunawa Marunda, North } \\
\text { Jakarta and Rusunawa Rawa Bebek, East Jakarta. } \\
\text { - The eviction of the Luar Batang settlement was conducted because } \\
\text { it violated the Regional Regulation on Development, Governor Ahok } \\
\text { planned to convert the surrounding area of the Luar Batang Mosque } \\
\text { into maritime and religious tourism. } \\
\text { - The eviction was carried out in three locations in the Luar Batang area } \\
\text { (the Kampung Akuarium, Pasar Ikan, and the Museum Bahari). }\end{array}$ \\
\hline 11 & Kalijodo, North Jakarta & 18-19 January 2016 & $\begin{array}{l}\text { A concrete lane was built along Kepanduan Street and utilized as a jogging } \\
\text { track, a Futsal field, and a park. The residents were relocated to Rusunawa } \\
\text { Marunda, Cilincing, North Jakarta and Rusunawa Pulogebang, East Jakarta. }\end{array}$ \\
\hline 12 & Rawajati, Pancoran, South Jakarta & September 2016 & $\begin{array}{l}\text { - Previously this eviction was planned to be carried out in } 2015 \text {, but } \\
\text { hundreds of residents of Rawajati, Pancoran, South Jakarta Villages } \\
\text { were standing guard in front of their homes to reject the eviction } \\
\text { conducted by the DKI Jakarta Provincial Government. } \\
\text { - The eviction was conducted by the Government to restore its function } \\
\text { as a green area. The residents were going to be relocated to Rusun } \\
\text { Marunda, North Jakarta. }\end{array}$ \\
\hline
\end{tabular}

There were at least 12 evictions carried out during his two years of leadership (Tambun, 2016).

The above data shows that the evictions were conducted to solve the flood problems which continuously haunted the capital city. According to Governor BTP, the rivers and dams would overflow if the heavy rains keep falling while the capacity of the river and the dam decrease due to the many buildings on it or on its banks (Saroh, 2017). The government must provide a larger reservoir for the rainwater by widening the rivers and dams through the normalization project.

The Deputy Governor, Djarot Saiful Hidayat, stressed that this effort was in accordance with Government Regulation No. 38 of 2011 on the River, which stated that the existing buildings on the riparian zone of a river should be regulated to return the river's function. It would be difficult to control and maintain the normalized river if there were buildings standing in the area since the normalization was conducted by building concrete walls, which means that an inspection road would be built on the river banks (Saroh, 2017). However, the government also provided a solution for the evicted people. In some cases, the DKI Provincial
Government offered to the affected residents to be relocated, compared this to (Córdoba, 2010). Affected families were given a direct solution in the form of affordable housing.

To date, the DKI Jakarta Government is still working on overcoming floods in Jakarta. Floods still occur in some points since the normalization process is still ongoing. The Head of Water Resources Unit of the DKI Jakarta Provincial Government stated that the current normalization process is at $60 \%$ of its target. The delay is due to a number of factors, such as land acquisition around the river and the residents' behavior of garbage disposal that clogged the channels. To mitigate the risk of flooding, the government prepares 145 pump houses, 421 stationary pumps, and 40 mobile standby pumps in residential areas to pump out water quickly (Paramaesti, 2017).

Meanwhile, the 2018-2019 rainy season still predicted to bring floods to Jakarta The Head of BBWS Ciliwung Cisadane stated that 129 Villages in Jakarta are prone to floods due to their location around the riverbanks which have not been normalized (Nailufar, 2018a). The delay is due to difficulties of clearing up residential settlements

Table 3.

\begin{tabular}{ccccc}
\hline Number of Areas & Time & Refugee & Casualties & The Max Depth. \\
\hline 25 Sub-Districts & $\begin{array}{c}\text { February, March, April } \\
\text { 2016 (average = 2 days) }\end{array}$ & 70,218 people & - & 2 meters \\
\hline 15 Sub-Districts & 21 September 2015 & 1,613 people & 2 people & 1.5 meter \\
\hline
\end{tabular}

Source: detik.com, $2017 b$ 
from the riverbanks area. BBWS Ciliwung Cisadane is dredging the river sediments to minimize the floods. However, this action would not as effective to prevent the flood as a normalization would.

\section{B. Jeremy Bentham and John Stuart Mill Utilitarianism.}

This began from a morality philosophy in the United Kingdom which then spread all over the English-speaking areas. It was introduced by David Hume (1711-1766). He believes that "good action" is an action that has a "utility", that the action brought happiness to a lot of people. Moral, for Hume, is the drive to produce or to prevent an action. Hume did not develop this idea in a comprehensive theory. Later, this idea was definitively formulated by Jeremy Bentham and John Stuart Mill in the late 18th and 19th centuries (Bertens, 1993, p. 247).

The first philosopher who described utilitarianism explicitly and systematically was Jeremy Bentham (1748-1832), an English philosopher and close friend of John Stuart Mill's father, James Mill. Bentham expressed utilitarianism in the first four chapters of his most famous book, An Introduction to the Principles of Morals and Legislation (1789) (Magnis-Suseno, 1997, p. 180). According to Bentham, basically, mankind is under the governance of two sovereign masters, pain and pleasure. However, by nature, human tend to pursue

pleasure and avoid pain (Bertens, 1993). As such happiness is achieved when we attain pleasure and free of pain. Since human behavior is directed at happiness, an action can be judged as good or bad, on how it can increase or decrease the happiness of as much of people as possible (Dimova-Cookson, 2003).

The morality of action must be determined by considering its utility to bring happiness to mankind, not just egoistic individual happiness. Thus, Utilitarianism overcomes egoism and justifies social attitudes. Utilitarianism justifies that sacrificing one's own interests or pleasures for the sake of others may be the highest moral value (Sudarminta, 2013). On that basis, Bentham stated the principle of utility: The Greatest Happiness of the Greatest Number (Poespoprodjo, 1999, p. 47). He found the principle in a pamphlet of "Essay on Government" (Harsono, 1989, p. 33).

He applied the principle of utility quantitatively, because according to him, the quality of pleasure is always the same, the only aspect that can be different is the quantity. Not only the greatest number but also the greatest happiness (Bentham, 1907). For that, Bentham developed the hedonic calculus. The sources of pleasure can be measured and calculated according to its intensity and duration, according to certainty to produce the feeling of pleasure, according to its propinquity or remoteness, according to purity and its extents and so on (Bertens, 1993). This calculation will result in a positive balance if the credit (pleasure) exceeds the debit (Bentham's ethics of utilitarianism can also be understood as utilitarianism action, regulation, egoistic, hedonic, and universal). According to him, the morality of all deeds can be calculated in this way (Veenhoven, 2012).

However, Bentham understands that we cannot spend so much time to count the amount of happiness that we would never do things that actually make us happy. In facts, Bentham never intended that the "hedonic calculus" will be used by the general public. He only intends to provide the method as a tool for politicians to help them enact regulations that maximize the general levels of happiness. As Bentham explained, the real purpose of the "hedonic calculus" is for formulating the legislation, to share happiness fairly with the entire community, just like Santa Claus (Bentham, 1982).

Meanwhile, John Stuart Mill is a philosopher, economist, and English social and political reformer. Mill was born in London in 1806, the son of James Mill, who was also a quite famous philosopher and a national economist. In the age of 13 , he had studied the works of the national economists such as Adam Smith and David Ricardo. He was in the "utilitarianism circle" around Jeremy Bentham which was the best friend of his father, James (Magnis-Suseno, 1997).

Mills still maintain the principle of utilitarianism, though not all Bentham's views. Their similarity is their views on happiness as the purpose in life. But Mill has his own view, that happiness does not have to be a direct experience. (Mill, 2017). People can be happy indirectly, for example by seeing the happiness of others and by seeing humanitarian improvements in general. Mill argued that pleasure is not the only motive in one's actions and attitudes (Harsono, 1989). The pursuit of pleasure and the avoidance of pain, in Mill's utilitarianism, is not an emotional matter, but a matter of rational calculation. From that rational calculation at the psychological level (psychological association), utilitarianism translates it into social life. The psychological association theory is based on the assumption that humans are naturally social, humans feel good when others feel good, eventually, there is a psychological association between the ideas of other people's pleasure and their own happiness (Magnis-Suseno, 1997).

Mill believes that human environment can shape their attitudes and actions. In the end, men 
would not only think about themselves. This is where the ruler carries out the duty of the state. They provide pleasure in accordance with the principle of the Greatest Happiness of the Greatest Number. In this theory, not only the good and bad consequences of each action need to be taken into account, but also the general rules underlying the action. (Sudarminta, 2013). Thus, an action is morally good, when it is in accordance with the prevailing rules in the morality system that promotes the greater good for society.

\section{Philosophical View on Eviction}

Philosophically, an action is considered as a good based on its intention and consequence. According to deontological theory by Immanuel Kant, a German philosopher, that to act in the morally right way, people must act from duty (Bertens, 1993). Based on that thinking, for example, it is considered a good act when a person jumps into the sea with the intention of rescuing a drowning person but fails since he cannot swim too. Kant's thinking is considered not absolute because good intentions are not enough if the perpetrator also becomes a victim of the noble act.

Meanwhile, John Stuart Mill and Jeremy Bentham as utilitarianism proponents believe that good action is defined by its good consequences. One of the strengths of utilitarianism is that they use clear and rational principles (Robertson \& Walter, 2007). By following this principle, the government has a clear guideline in the formulation of policies to regulate society. Another strength of utilitarianism is that this theory pays attention to the results of the actions as the determinant of its ethical quality. Furthermore, in On Liberty (1859), Mill emphasizes that the actions that cause happiness for a greater amount of people are justified, though the action might cause a few people to be unhappy. Here the individual freedom is guaranteed, and the state can step in if their actions endanger others.

It is on this basis that the eviction policy can be justified because the displacement of a handful of residents on the banks of the river to normalize the river and to provide green areas save millions of Jakarta residents from floods. In fact, the main goal of the eviction is certainly for the greater benefit of the community as a whole (compare with the study of Sulistyo (2017).

In this case, the objective basis for assessing a behavior or action is the benefits or utilities of such behavior or action: whether the act of eviction is the right action or the act of building a settlement on the riverbank is harmful. Legally, erecting a building on the riverbank is a violation of the law.
According to PP No. 38 of 2011 on Rivers, a riparian zone includes the virtual line on the right and left of the river designated to maintain its function as a waterway. If the condition of this zone is maintained, then the river will be able to protect the surrounding environment from the danger of floods and landslides (Fitrianti \& Fadhilah, 2018; Wolff, 2008). Therefore, the DKI Jakarta Provincial Government conducted the river normalization program to avoid losses caused by floods. The normalization effort was carried out by dredging the river, cleaning up of garbage, and removing buildings and communities around the river banks to widened and improve the environment around the river (see also study by Syafi'i SJ, 2017).

Settlements around the riverbanks can cause floods, which of course will be followed by other social problems, such as displacement due to flooded houses, disease, and disruption in economic activities. Floods will always happen every year in Jakarta if it not immediately addressed. There will be more material losses for people, due to the continuing floods problem every rainy season.

In addition to utility value, utilitarianism is also universal since it emphasizes the sacrifice of personal interests or pleasure for the pleasure of a greater number of people (Thomson \& Kolak, 2016). Mill formulate it in the associationist psychology theory, which is based on the assumption that humans are naturally social, humans feel good when others feel good, eventually, there is a psychological association between the ideas of other people's pleasure and their own happiness. This theory is in line with the actions of some people whose homes are on the riverbanks and are willing to be evicted to bring happiness to many people because the only way to reduce floods and beautify the city is to demolish improper buildings. After the eviction, the normalization project can be carried out to return the river to its normal function and the community does not need to worry about floods (Belarminus, 2016). With such actions, there is no longer a difference between other people pleasure and their own. Happiness is felt as long as it brings pleasure to as many people as possible.

Even though the government displaced the residents, the government does not neglect its responsibility. The displaced residents were relocated to new housing prepared by the government. The condition of the housing area (rusunawa) managed by the DKI Provincial Government is more comfortable than their previous houses so that residents' health is better because they do not live in the slums area anymore. The units were also rent-free for the first three months. The rent of IDR300,000 per 
month starting in the fourth month (Sari, 2016). Since providing horizontal housing is increasingly difficult, the government's policy of providing low rent flats for the disadvantaged people in urban areas is appropriate, considering that the government has to provide good quality and large capacity housing on limited land. Because a home must be a comfortable, decent, and safe place to live. In addition, the need for a home is related to one's level of satisfaction (Sulistiyani, 2002, pp. 332-342).

Regarding satisfaction, Bentham's utilitarianism uses the hedonic calculus by measuring and calculating sources of pleasure according to their intensity and duration (Mautner, 1997). Bentham's utilitarianism uses the hedonic calculus by measuring and calculating sources of pleasure according to their intensity and duration (Mautner, 1997). The calculation resulting in a positive balance if the pleasure (credit) exceeds the pain (debit). We can calculate the amount of pleasure given during the eviction based on Bentham calculation. First, the people around or outside the riverbanks are free from floods and its harmful effects. Second, the displaced residents are resettled in new rental housings leased by the government at an affordable price. Rental fees are only used for maintenance and cleaning costs. Third, the residents are provided with supporting facilities, starting from the free Trans Jakarta transportation, Kartu Jakarta Pintar (KJP), which can be used to pay for children's school needs, to health services. The government provides eighty percent more subsidies for the poor affected by the evictions (Jordan, 2017). As such, the hedonic calculus calculation for the eviction produces a positive balance of happiness because the pleasure credit received is more than the debit of pain due to being evicted.

Pleasure is good and pain is bad for the utilitarian, whatever causes happiness and reduces pain is morally right, and whatever causes pain or unhappiness is morally wrong (Burns, 2005). In other words, utilitarianism is interested in the consequences of an action: if the action provides a good consequence, then the action is correct, if the action provides a bad consequence, then the action is wrong. This principle also helps every time we have to choose an action or a public policy that must be applied. Utilitarianism suggests that we take the one choice that has the best overall consequences for everyone involved (Gandjour, 2007).

\section{ConCLUSION}

The eviction policy carried out by the DKI Jakarta Government is justified in the philosophical perspective of utilitarianism. Eviction policy removed a handful of residents on the river banks to save millions of DKI Jakarta residents from the annual flood disaster. Based on the Utilitarianism principle, since the evictions create more good consequences compared to the bad consequences, this act is morally justified since it provides more benefit for the greater number of people. This view is in accordance with the general characteristics of utilitarianism which are critical, rational, teleological, and universal.

The DKI Jakarta Government decision to resettle the residents of the problematic areas, especially slums, is not only because of the negative impacts caused by floods but also because the current the settlements are ineffective. The main objective of the eviction is for the public interest. This is in line with the main principle of utilitarianism, the Greatest Happiness of the Greatest Number, which emphasizes the morality of an action determined by considering its utility to achieve happiness for all human beings, not egoistic individual happiness as embraced by the classical hedonism philosophy. As such, the right government policies are policies that have the greatest utility for the community. For this reason, the Regional Medium-Term Development Plan for the Special Capital Region of Jakarta (RPJMD DKI Jakarta) specifically prioritizes the Jakarta flood problem. The government builds and provides several livable vertical flats for DKI residents as one of the solutions for the housing problems.

In addition, from a legal perspective, evictions are not violating the laws as stated in Law No. 2 of 2012 on Land Procurement for Public Interest and Development. This is also a fulfillment of Article 28H Paragraph 1 of the 1945 Constitution and Article 5 Paragraph 1 of Law No. 1 of 2011 on Housing and Settlement Areas. The government performs its duties to provide and defend the public interest. The government has fulfilled its responsibilities regarding the eviction policies based on the ethical principles of utilitarianism.

Although the utilitarianism concept alone is not sufficient as the only ethical principle, at least this concept provides a guide to think critically and rationally to asses rules that we do not understand its usefulness for our personal survival and also for the wider community. The principle of freedom contained in Utilitarianism teaches every moral actor to respect each other for mutual order. In the event of conflicting interests among moral actors, 
utilitarianism ethics can be used as a standard to evaluate and choose the one for the greater benefit of the people.

\section{ACKNOWLEDGMENT}

I would like to thank you for the priests who taught at the STF Driyarkara who gave me a lot of understanding of philosophy. Especially to Prof. Justinus Sudarminta and Prof. Franz Magnis Suseno who has given much input in the form of suggestions and criticisms regarding this manuscript.

\section{REFERENCES}

Abraham, R., Lubis, D. I., Indrawan, M., \& Fachrudin, R. (2014). Visa Masuk Kota: Alternatif Kebijakan Kaum Urban Untuk Mengatasi Kepadatan Penduduk Jakarta. Program Kreativitas Mahasiswa - Gagasan Tertulis. Retrieved from http://artikel.dikti.go.id/index.php/PKMGT/ article/view/144

Albajili, M. C. M., Latifa, R., \& Fitri, N. R. Al. (2018). Masih Ada: Laporan Penggusuran Paksa di Wilayah DKI Jakarta 2018. Retrieved from https://www.bantuanhukum.or.id/web/ wp-content/uploads/2018/10/laporanpenggusuran-jakarta-2018.pdf

Alwasilah, A. C. (2003). Pokoknya Kualitatif: DasarDasar Merancang dan Melakukan Penelitian Kualitatif. Jakarta: Pustaka Jaya.

Baujard, A. (2013). Utilitarianism and AntiUtilitarianism. SSRN Electronic Journal. https://doi.org/10.2139/ssrn.2357441

Belarminus, R. (2016, November 15). Setelah Penggusuran, Normalisasi Ciliwung di Cawang Segera Dimulai (I. Rastika, Ed.). https:// doi.org/https://megapolitan.kompas.com/ read/2016/11/15/12314501/setelah. penggusuran.normalisasi.ciliwung.di.cawang. segera.dimulai

Bentham, J. (1907). Happiness Is the Greatest Good (pp. 1-15). pp. 1-15. Retrieved from https://philosophy.lander.edu/intro/articles/ bentham-a.pdf

Bentham, J. (1982). An Introduction to The Principles of Morals and Legislation (1781 Ed.) (pp. 14-18). pp. 14-18. Retrieved from https://www.reed. edu/Humanities/hum220/syllabus/2010-11/ Bentham-Principles.pdf

Bertens, K. (Kees). (1993). Etika. Jakarta: Gramedia Pustaka Utama.

Bromell, D. (2012). Doing the right thing: Ethical dilemmas in public policy making. Retrieved from https://www.researchgate.net/ publication/289129763_Doing_the_right_ thing_Ethical_dilemmas_in_public_policy_ making

Burns, J. H. (2005). Happiness and Utility: Jeremy Bentham's Equation. Utilitas, 17(1), 46-61. https://doi.org/10.1017/ S0953820804001396

Córdoba, M. B. F. de. (2010). Public Interest in Political Philosophy. A Necessary Ethical and Regulatory Concept for Territorial Planning. Boletín de La Asociación de Geógrafos Españoles, (53), 381-386. Retrieved from https://www. researchgate.net/publication/289430445_ Public_interest_in_political_philosophy_a_ necessary_ethical_and_regulatory_concept_ for_territorial_planning

Dimova-Cookson, M. (2003). Bentham, Mill and Green on the nature of the good. Journal of Bentham Studies, 6, 1-18. Retrieved from https://www.researchgate.net/ publication/32885225_Bentham_Mill_and_ Green_on_the_Nature_of_the_Good

Fitrianti, N. A., \& Fadhilah, N. L. (2018). Relokasi Permukiman Warga Bantaran Sungai Ciliwung di Provinsi Jakarta. Lentera Hukum, 5(2), 277. https://doi.org/10.19184/ejlh.v5i2.6788

Gandjour, A. (2007). Is it Rational to Pursue Utilitarianism? Ethical Perspectives, 14(2), 139-158. https://doi.org/10.2143/ EP.14.2.2023965

Harsono, A. (1989). Utilitarisme John Stuart Mill. Sekolah Tinggi Filsafat Driyarkara.

Haryatmoko. (2013). Etika Publik untuk Integritas Pejabat Publik dan Politisi. Jakarta: Gramedia Pustaka Utama.

Human Rights Watch. (2006). Masyarakat yang Tergusur: Pengusiran Paksa di Jakarta (Vol. 18). Retrieved from https://www. hrw.org/reports /2006/indonesia0906/ indonesia0906sumandrecsBIweb.pdf

Human Rights Watch. (2011). World Report. Retrieved from https://www.hrw.org/sites/ default/files/related_material/wr2011_book_ complete.pdf

Ibrahim, H. R. (2005). Penggusuran dalam perspektif HAM. Michigan: Pustaka Cidesindo.

Insidejakarta.com. (2018, September 7). Penggusuran Memiliki Dampak Positif atau Negatif Bagi Ekonomi Rakyat Jakarta? Retrieved from Insidejakarta.com website: https://www.insidejakarta.com/ketahuilah/ dampak-penggusuran/

Januardy, A. F. (2015). KAMI TERUSIR: Laporan Penggusuran Paksa di Wilayah DKI Jakarta Januari-Agustus 2015. Retrieved from https:// www.bantuanhukum.or.id/web/wp-content/ uploads/2015/08/Laporan-PenggusuranPaksa-Jakarta.pdf 
Januardy, A. F., Achmadi, J. C., \& Fortuna, C. I. (2016). Seperti Puing: Laporan Penggusuran Paksa di Wilayah DKI Jakarta Tahun 2016. Retrieved from https://www.bantuanhukum.orid/web/ wp-content/uploads/2017/04/LaporanPenggusuran_LBHJAKARTA_2016.pdf

Jordan, R. (2017, February 20). Ahok Bangun Rusunawa untuk Warga DKI, Berapa Bayar Sewanya? Retrieved from detikFinance website: https://finance.detik.com/ properti/d-3426879/ahok-bangun-rusunawauntuk-warga-dki-berapa-bayar-sewanya

Magnis-Suseno, F. (1997). 13 TOKOH ETIKA, Sejak Zaman Yunani Sampai Abad ke-19. Yogyakarta: Kanisius.

Mautner, T. (1997). The Penguin Dictionary of Philosophy. Penguin Books.

McGee, R. W. (2004). Property Rights vs. Utilitarianism: Two Views of Ethics. SSRN Electronic Journal, 27(Fall), 85-112. https:// doi.org/10.2139/ssrn.546344

Mill, J. S. (2017). Utilitarianism. Retrieved from https://www.earlymoderntexts.com/assets/ pdfs/mill1863.pdf

Mirah Sakethi. (2010). Mengapa Jakarta Banjir? Pengendalian Banjir Pemerintah Provinsi DKI Jakarta. Jakarta: Mirah Sakethi.

Nailufar, N. N. (2018a, September 13). Jakarta Masih Terancam Bencana Banjir (E. Patnistik, Ed.). Retrieved from Kompas.com website: https://megapolitan.kompas.com/ $\mathrm{read} / 2018 / 09 / 13 / 09413271 /$ jakarta-masihterancam-bencana-banjir?page $=$ all

Nailufar, N. N. (2018b, December 7). Ini 12 Titik Langganan Banjir di Jakarta Selatan (D. Maharani, Ed.). Retrieved from Kompas.com website: https://megapolitan.kompas.com/ read/2018/12/07/20422241/ini-12-titiklangganan-banjir-di-jakarta-selatanNugroho, B. P. (2017, February 22). Banjir Jakarta di 5 Tahun Terakhir. Retrieved from Detik. com website: https://news.detik.com/ berita/d-3429219/banjir-jakarta-di-5-tahunterakhir

Osifo, C. (2015). Evaluating Governance and Management in Africa; A utilitarian Perspective (No. Working Papers 8). Retrieved from https://www.univaasa.fi/materiaali/pdf/ isbn_978-952-476-599-2.pdf

Paramaesti, C. (2017, October 20). Ancaman Banjir di Jakarta, Normalisasi Sungai Baru 60 Persen (U. Widyanto, Ed.). Retrieved from Tempo.co website: https://metro.tempo.co/ $\mathrm{read} / 1026535 /$ ancaman-banjir-di-jakartanormalisasi-sungai-baru-60-persen

Poespoprodjo, W. (1999). Filsafat Moral: Kesusilaan
Dalam Teori dan Praktek. Jakarta: Pustaka Grafika.

Pravitasari, A. E. (2018). Dampak Urbanisasi dan Perkembangan Perkotaan di Jabodetabek dan Sekitarnya Serta Pengaruhnya pada Peningkatan Degradasi Lingkungan. Jabodetabek Study Forum. Retrieved from http://p4w.ipb.ac.id/jabodetabek-studyforum/uploads/files/The-1st-JabodetabekDiscussion-Series-in-2018-Andrea Emma-PHandout.pdf

Prihatin, R. B. (2014). Fenomena Penggusuran di Jakarta. Info Singkat Kesejahteraan Sosial, VI(17), 9-12. Retrieved from http://berkas. dpr.go.id/puslit/files/info_singkat/Info Singkat-VI-17-I-P3DI-September-2014-31.pdf

Purnamasari, N. (2016, September 28). Gusur Rumah Warga di Bantaran Kali Bukit Duri, Ahok: Saya Tidak Ada Pilihan. Retrieved from Detik.com website: https://news.detik.com/ berita/d-3308444/gusur-rumah-warga-dibantaran-kali-bukit-duri-ahok-saya-tidak-adapilihan

Purwantini. (2016). Urbanisme, Urbanisasi, dan Masyarakat Urban di Jakarta dalam Novel Senja di Jakarta. ATAVISME, 19(2), 162. https://doi. org/10.24257/atavisme.v19i2.192.162-175

Reinhart, F, C. (2015). Summary for Policymakers. In Intergovernmental Panel on Climate Change (Ed.), Climate Change 2013 - The Physical Science Basis (pp. 1-30). https://doi. org/10.1017/CB09781107415324.004

Robertson, M., \& Walter, G. (2007). A Critical Reflection on Utilitarianism as the Basis for Psychiatric Ethics. Part I: Utilitarianism as Ethical Theory. Journal of Ethics in Mental Health, 2(1), 1-4. Retrieved from https://jemh. ca/issues/v2n1/documents/JEMH_V2N1_ Article1_UtilitarianismAsAnEthicalTheory.pdf

Sabrina S., E. (2017). Konstruksi Sosial Masyarakat Tentang Penggusuran Lahan (Studi Kasus Penggusuran Lahan di Wilayah Kelurahan Gunung Anyar). Jurnal Universitas Airlangga, 6(1),1-18. Retrieved from http://journal.unair. ac.id/Kmnts@konstruksi-sosial-masyarakattentang-penggusuran-lahan-(studi-kasuspenggusuran-lahan-di-wilayah-kelurahangunung-anyar)-article-11927-media-135category-8.html

Sari, N. (2016, April 28). Relokasi Warga ke Rusun yang Problematik. Retrieved from Kompas. com website: https://megapolitan.kompas. $\mathrm{com} / \mathrm{read} / 2016 / 04 / 28 / 08180571 /$ Relokasi. Warga.ke.Rusun.yang.Problematik.?page $=$ all

Saroh, M. (2017, February 21). Kebijakan Ahok, Normalisasi Sungai Bisa Atasi Banjir - Tirto.ID. 
Retrieved from Tirto.id website: https://tirto. id/kebijakan-ahok-normalisasi-sungai-bisaatasi-banjir-cjpx

Saudale, V., Tambun, L. T., Purnamasari, D. M., \& DAS. (2016, October 18). Ciliwung Tak Lagi Sumber Petaka. Retrieved from Beritasatu. com website: https://www.beritasatu.com/ megapolitan/393435/ciliwung-tak-lagisumber-petaka

Soemarwi, Vera W S. (2016). Program Pembangunan Jakarta: Normalisasi Kali Ciliwung dengan Merampas Tanah Warga [Studi Kasus Putusan Nomor: 205/G/2016/PTUNJKT]. Ciliwungmerdeka.Org. Retrieved from https://ciliwungmerdeka.org/wp-content/ uploads/2017/02/FGD-Bedah-Putusan-TUNLBH-Jakarta-10-Februari-2017.pdf

Soemarwi, Vera Wheni S. (2017). Tinjauan NormatifEmpiris Asas Partisipatif dalam Perencanaan Pembangunan Kota: Normalisasi Kali Ciliwung di Bukit Duri. Jurnal Muara Ilmu Sosial, Humaniora, Dan Seni, 1(1), 232-239. https:// doi.org/10.24912/jmishumsen.v1i1.355

Sudarminta, J. (2013). ETIKA UMUM, Kajian tentang Beberapa Masalah Pokok dan Teori Etika Normatif. Yogyakarta: Kanisius.

Sugiyono. (2015). Metode Penelitian Kuantitatif, Kualitatif dan R\&D. Bandung: Alfabeta.

Sulistiyani, A. T. (2002). Problema dan Kebijakan Perumahan di Perkotaan. Jurnal Ilmu Sosial Dan Ilmu Politik, 5(3), 327-344. https://doi. org/10.22146/jsp.11101

Sulistyo, E. (2017). Tindakan Kekerasan Dalam Penggusuran yang Dilakukan Aparatur Negara di Kota Bandung (Kajian Dalam Prespektif Hak Asasi Manusia) (Universitas Islam Indonesia; Vol. 91). Retrieved from https://dspace.uii. ac.id/handle/123456789/3702

Suseno, F. M. (1979). Etika Umum: Masalah-Masalah Pokok Filsafat Moral. Yogyakarta: Yayasan Kanisius.

Syafi'i SJ, A. (2017). Fliqh Proletar: Rekonstruksi Nalar Kepentingan Umum dalam Kasus Pembebasan Tanah untuk Pembangunan
Menuju Ke Arah Transformasi Sosial yang Progresif-Humanis. FIKROTUNA, 3(1). https:// doi.org/10.32806/jf.v3i1.2711

Tambun, L. T. (2016, September 29). Selama Menjadi Gubernur DKI, Ahok Telah Lakukan 12 Penggusuran. Retrieved from Beritasatu. com website: https://www.beritasatu.com/ megapolitan/389284/selama-menjadigubernur-dki-ahok-telah-lakukan-12penggusuran

Thomson, G., \& Kolak, D. (2016). The Longman Standard History of Medieval Philosophy. London: Routledge.

Veenhoven, R. (2012). Happiness as a Public Policy Aim: The Greatest Happiness Principle. In A. L. and S. Joseph (Ed.), Positive Psychology in Practice (Chapter 39, pp. 658-678). https:// doi.org/10.1002/9780470939338.ch39

Waryono, T. (2002). Fenomena Banjir di Wilayah Perkotaan (Studi kasus banjir DKI Jakarta 2002) (pp. 16-19). pp. 16-19. Retrieved from https://staff.blog.ui.ac.id/tarsoen.waryono/ files /2009/12/20-fenomena-banjir-di-wilperkotaan.pdf

Widodo, G. A. (2018). Kontestasi Diskursus dalam Penggusuran Kampung Kalijodo Jakarta (Fakultas Ilmu Sosial dan Ilmu Politik UIN Syarif Hidayatullah). Retrieved from http://repository.uinjkt.ac.id/dspace / handle/123456789/42923

Wigati, R., \& Soedarsono. (2016). Normalisasi Sungai Ciliwung Menggunakan Program HECRAS 4.1 (Studi Kasus Cililitan - Bidara Cina). Jurnal Fondasi, 5(1), 1-12. Retrieved from http://jurnal.untirta.ac.id/index.php/jft/ article/view/1242

Wolff, B. G. (2008). Environmental Studies and Utilitarian Ethics. Bioscene, 34(2), 6-11. Retrieved from https://www.researchgate. net/publication/289911991_Environmental_ studies_and_utilitarian_ethics

Zed, M. (2004). Metode Penelitian Kepustakaan. Jakarta: Yayasan Pustaka Obor Indonesia. 